\title{
Thermochemistry of Bithiophenes and Thienyl Radicals. A Calorimetric and Computational Study
}

\author{
Manuel A. V. Ribeiro da Silva,* Ana Filipa L. O. M. Santos, and José R. B. Gomes ${ }^{\dagger}$ \\ Centro de Investigação em Química, Department of Chemistry, Faculty of Science, University of Porto, Rua do \\ Campo Alegre, 687, P-4169-007 Porto, Portugal
}

\author{
María Victoria Roux, Manuel Temprado, Pilar Jiménez, and Rafael Notario* \\ Instituto de Química Física “Rocasolano”, CSIC, Serrano 119, 28006 Madrid, Spain
}

Received: June 12, 2009; Revised Manuscript Received: August 20, 2009

\begin{abstract}
The relative stabilities of $2,2^{\prime}$ - and $3,3^{\prime}$-bithiophenes were evaluated by experimental thermochemistry and the results compared with data obtained from state of the art calculations, which were also extended to 2,3'bithiophene. The standard ( $p^{\circ}=0.1 \mathrm{MPa}$ ) molar enthalpies of formation of crystalline $2,2^{\prime}$-bithiophene and $3,3^{\prime}$-bithiophene were calculated from the standard molar energies of combustion, in oxygen, to yield $\mathrm{CO}_{2}$ (g) and $\mathrm{H}_{2} \mathrm{SO}_{4} \cdot 115 \mathrm{H}_{2} \mathrm{O}$, measured by rotating-bomb combustion calorimetry at $T=298.15 \mathrm{~K}$. The vapor pressures of these two compounds were measured as a function of temperature by Knudsen effusion massloss technique. The standard molar enthalpies of sublimation, at $T=298.15 \mathrm{~K}$, were derived from the Clausius-Clapeyron equation. The experimental values were used to calculate the standard $\left(p^{\circ}=0.1 \mathrm{MPa}\right)$ enthalpies of formation of the title compounds in the gaseous phase; the results were analyzed and interpreted in terms of enthalpic increments and molecular structure. Standard ab initio molecular orbital calculations at the G3(MP2)//B3LYP level were performed. Enthalpies of formation, using homodesmotic reactions, were calculated and compared with experimental data. The computational study was also extended to the isomeric compound 2,3'-bithiophene. Detailed inspections of the molecular and electronic structures of the compounds studied were carried out. Finally, bond dissociation enthalpies (BDE) and enthalpies of formation of thienyl radicals were also computed.
\end{abstract}

\section{Introduction}

Oligothiophenes and polythiophenes have attracted enormous attention due to their unusual electrical and nonlinear optical properties, making these compounds interesting materials for organic electronics and optoelectronics. ${ }^{1-4}$ The molecular origin of these properties is related with the intramolecular delocalization of the $\pi$-electrons along the conjugated chain, which is governed by the internal rotation of the thiophene units around the interannular single bonds. The degree of planarity of the chain determines the width of the $\pi$-bands and, thereby, the electrical and optical properties of both the polymer and the oligomers. ${ }^{5}$

Oligothiophenes and polythiophenes are being largely investigated and have found important applications in the area of new materials because of their good chemical, electrochemical, and thermal stabilities, electrical conductivity in the oxidized state, structural versatility, ease of synthesis (chemical, ${ }^{6-9}$ or electrochemical ${ }^{7-9}$ ), and low cost of production. The $\alpha$-conjugated compounds are among the most intensively investigated organic materials for light-emitting diodes (LEDs), ${ }^{6,7,10-17}$ fieldeffect transistors (FETs), ${ }^{16-26}$ thin-film transistors (TFTs), ${ }^{27-31}$ and conducting molecular wires linking active elements to each other. $^{32}$ They are also used in rechargeable batteries, ${ }^{7,8,33}$ antistatic coating, artificial noses and muscles, nanoelectronic and optical devices, microwave absorbing material, memory devices, solar cells, ${ }^{7}$ gas sensors, ${ }^{7,34,35}$ and, finally, biological

* To whom correspondence should be addressed: risilva@fc.up.pt (M. A. V. Ribeiro da Silva); rnotario@iqfr.csic.es (R. Notario).

Present address: CICECO, Department of Chemistry, University of Aveiro, Campus Universitário de Santiago, P-3810-193 Aveiro, Portugal.

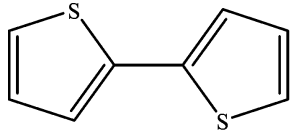

2,2'-Bithiophene

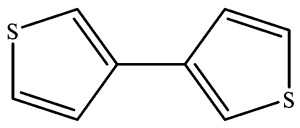

3,3'-Bithiophene
Figure 1. Structural formulas of the compounds studied in this work.

and chemical sensors, finding applications in areas of diagnostics, therapeutics, and drug screening. ${ }^{11,36,37}$

Bithiophenes, and in particular 2,2'-bithiophene, are the main building blocks of these conducting organic polymers. Therefore, the two-ring compound, 2,2'-bithiophene, is of interest as the most simple model to gain information about the conformation of larger polythiophene chains and has been intensively investigated both experimentally ${ }^{38-43}$ and theoretically ${ }^{44}$ (see Supporting Information for more details).

Despite their importance, as exposed above, available thermochemical data for these organosulfur compounds are still limited. These data, e.g., enthalpies of formation in the gaseous state, are important for understanding the relationships between structure, energetics, and reactivity.

As part of our interest on the energetics of thiophene derivatives, previously reported, ${ }^{45-60}$ we have now studied the thermochemistry of two bithiophene isomers, namely, 2,2'bithiophene and 3,3'-bithiophene, whose structural formulas are represented in Figure 1.

In this paper we report the standard $\left(p^{\circ}=0.1 \mathrm{MPa}\right)$ molar energies of combustion, in oxygen, at $T=298.15 \mathrm{~K}$, determined 
by rotating bomb combustion calorimetry, for the two title bithiophene isomers. The Knudsen effusion mass-loss technique was used to measure the vapor pressures as a function of temperature of the two crystalline isomers. From the temperature dependence of the vapor pressure, the molar enthalpies and entropies of sublimation at the mean temperature of the experimental temperature range were derived, through the Clausius-Clapeyron equation. Standard molar enthalpies, entropies, and Gibbs energies of sublimation, at the temperature of $298.15 \mathrm{~K}$, were calculated using estimated values for the heat capacity differences between the gas and the crystal phases of each studied compound. G3(MP2)//B3LYP calculations were performed aiming to obtain additional thermochemical information about $\mathrm{C}-\mathrm{C}$ and $\mathrm{C}-\mathrm{H}$ bond dissociation enthalpies (BDEs) in bithiophenes and thiophene, respectively. Finally, standard molar gas-phase enthalpies of formation, at $T=298.15 \mathrm{~K}$, for the three different bithiophenes and for the two thienyl radicals were also computed.

\section{Experimental Section}

Compounds and Purity Control. The two studied isomers were commercially obtained from Sigma-Aldrich Chemical Co. with the following assessed purities: 2,2'-bithiophene (CAS 492 97-7), mass fraction 0.994, and 3,3'-bithiophene (CAS 317256-3), mass fraction 0.991, according to the respective certificate of analysis. Prior to its use, both compounds were purified by successive vacuum sublimations and the final purity of each one was checked by GLC and d.s.c., being found to be greater than 0.9999 . The samples of 2,2'- and 3,3'-bithiophenes were studied by d.s.c over the temperature range between $T=298.15$ $\mathrm{K}$ and their melting points, $T=304.2 \mathrm{~K}$ and $T=406.9 \mathrm{~K}$, respectively, and no transitions in the solid state were observed over these intervals.

The benzoic acid used in the calibration of the bomb was the NIST Standard Reference Material 39i. Thianthrene $\left(\mathrm{C}_{12} \mathrm{H}_{8} \mathrm{~S}_{2}\right)$, used as reference material for rotating bomb combustion calorimetry of organosulfur compounds, was supplied by Sigma-Aldrich Chemical Co., with a mass fraction purity of 0.99 and purified by zone melting.

The specific density of $2,2^{\prime}$-bithiophene is $\rho=1.44 \mathrm{~g} \cdot \mathrm{cm}^{-3}{ }^{61}$ It was assumed that $3,3^{\prime}$-bithiophene has the same specific density of 2,2'-bithiophene.

Differential Scanning Calorimetry. A differential scanning calorimeter (model Perkin-Elmer, Pyris 1) was used to control the purity and to study the existence of possible phase transitions in the sample. Its temperature and power scales were calibrated, ${ }^{62-64}$ at heating rates of 0.04 and $0.17 \mathrm{~K} \mathrm{~s}^{-1}$. The temperature scale was calibrated by measuring the melting temperature of the recommended high-purity reference materials: hexafluorobenzene, benzoic acid, tin, and indium. ${ }^{65}$ The power scale was calibrated using high-purity indium (mass fraction $>0.99999$ ) as reference material. After calibration, several runs with highpurity benzoic acid and indium as reference materials ${ }^{65}$ were performed under the same conditions as the experimental determinations for checking throughout the entire process. ${ }^{66}$ Thermograms of samples hermetically sealed in aluminum pans were recorded in a nitrogen atmosphere. All the pans were weighed before and after the experiments in order to confirm that no product had volatilized.

Combustion Calorimetry. The standard molar enthalpies of combustion of the two bithiophene isomers studied in this work were measured at the University of Porto, using a rotating-bomb calorimeter equipped with a tantalum-lined combustion bomb. ${ }^{45}$ The measuring procedure and the detailed description of the apparatus have been described, ${ }^{45,67}$ so only a short description will be given here.

The calibration of the calorimeter has been made in the conventional way, as previously described by Coops et al., ${ }^{68}$ from the combustion of benzoic acid thermochemical standard NBS 39i. From 10 combustion experiments as described before ${ }^{45}$ the energy equivalent of the calorimeter, for an average mass of $3965.0 \pm 0.1 \mathrm{~g}$ of water added to the calorimeter, was found to be $\varepsilon$ (calor) $=20369.0 \pm 2.3 \mathrm{~J} \cdot \mathrm{K}^{-1}(0.011 \%)$; the quoted uncertainty is the standard deviation of the mean.

The temperatures of the calorimetric liquid were measured as reported before ${ }^{45}$ with the LABTERMO program ${ }^{69}$ used for data acquisition and control of the calorimeter temperature. The procedure described by Waddington et al. for combustion calorimetry of organosulfur compounds was followed. ${ }^{70}$ The compounds, in pellet form, were ignited in oxygen at a pressure of $3.04 \mathrm{MPa}$ with a volume of $15.00 \mathrm{~cm}^{3}$ of desionized water added to the bomb. Due to its volatility, the samples of $2,2^{\prime}$ bithiophene were enclosed in previously weighed polyester bags of Melinex, $0.025 \mathrm{~mm}$ of thickness, with the massic energy of combustion, $\Delta_{\mathrm{c}} u^{\circ}=-22902 \pm 5 \mathrm{~J} \cdot \mathrm{g}^{-1},{ }^{71}$ a value that was confirmed in our laboratory, using the technique of Skinner and Snelson. ${ }^{71}$

The ignition temperatures were chosen so that the final temperatures were as close as possible to $T=298.15 \mathrm{~K}$. Rotation of the bomb was started when the temperature rise of the main period reached about 0.63 of its total value and continued throughout the experiment. Corrections for the electrical energy of ignition ${ }^{45}$ and for the energy of combustion of the cotton thread fuse, of which the empirical formula is $\mathrm{CH}_{1.686} \mathrm{O}_{0.843}$, and $\Delta_{\mathrm{c}} u^{\circ}=-16240 \mathrm{~J} \cdot \mathrm{g}^{-1},{ }^{72}$ a value that was confirmed in our laboratory, were performed as described before. ${ }^{45}$ The amount of nitric acid produced in each experiment was determined by Devarda's alloy method $;^{73}$ the respective energetic correction based on $-59.7 \mathrm{~kJ} \cdot \mathrm{mol}^{-1}$ for the standard molar energy of formation in which $0.1 \mathrm{~mol} \cdot \mathrm{dm}^{-3} \mathrm{HNO}_{3}(\mathrm{aq})$ is formed from $\mathrm{O}_{2}(\mathrm{~g}), \mathrm{N}_{2}(\mathrm{~g})$, and $\mathrm{H}_{2} \mathrm{O}(\mathrm{l}){ }^{74}$ An estimated pressure coefficient of massic energy $(\partial u / \partial p)_{T}$, at $T=298.15 \mathrm{~K}$, was assumed to be $-0.2 \mathrm{~J} \cdot \mathrm{g}^{-1} \cdot \mathrm{MPa}^{-1}$, for each compound ${ }^{75}$ and the standard state corrections, $\Delta U_{\Sigma}$, were calculated by the procedures given by Hubbard et al. ${ }^{76}$

All the necessary weighings for the combustion experiments were made in a Mettler Toledo 245 balance, sensitivity $\pm 1 \times$ $10^{-5} \mathrm{~g}$, and corrections from apparent mass to true mass were made.

The relative atomic masses used for the elements were those recommended by the IUPAC Commission in 2005 . $^{77}$

Vapor Pressure Measurements. The vapor pressures of the two bithiophene isomers were measured, at several temperatures, by the mass-loss Knudsen technique. 2,2'-Bithiophene, due to its low melting point, was studied in an apparatus that enables work at temperatures under room temperature and the simultaneous operation of three Knudsen cells, with three different effusion holes. A detailed description of this apparatus, procedure, and working technique and the results obtained with two test substances (benzoic acid and ferrocene) have been published in a previous work. ${ }^{78}$ This apparatus will be referred as Knudsen-1 from now on. For 3,3'-bithiophene, the vapor pressures were measured, at several temperatures, using a Knudsen effusion apparatus which enables the simultaneous operation of nine aluminum effusion cells that are contained in cylindrical holes inside three aluminum blocks, each one with three cells. From now on, this apparatus will be named Knudsen2. Each block is maintained at a constant temperature, which 
can be different from the other two blocks. This apparatus, the measuring procedure, and technique as well as the results obtained with test substances were reported before. ${ }^{79}$

For each bithiophene isomer, the measurements were extended through a temperature interval of ca. $20 \mathrm{~K}$ chosen to correspond to measured vapor pressures in the range $0.1-1.0$ $\mathrm{Pa}$. The vapor pressure, $p$, of the compound in an effusion experiment is calculated by eq 1 , knowing the mass of sublimed compound (determined by weighing the effusion cells to \pm 0.01 $\mathrm{mg}$, before and after each effusion experiment), $m$, during a convenient effusion time period $t$, at the temperature $T$ of the experiment, in a system evacuated to a pressure near to $1 \times$ $10^{-4} \mathrm{~Pa}$

$$
p=\left(m / A_{\mathrm{o}} w_{\mathrm{o}} t\right)(2 \pi R T / M)^{1 / 2}
$$

where $R$ represents the gas constant, $M$ is the molar mass of the effusing vapor, $A_{\mathrm{o}}$ is the area of the effusion orifice, and $w_{\mathrm{o}}$ is the respective Clausing factor, calculated by eq 2

$$
w_{\mathrm{o}}=\{1+(3 l / 8 r)\}^{-1}
$$

where $l$ is the thickness of the effusion hole and $r$ is its radius.

For 2,2'-bithiophene, studied in the Knudsen-1 apparatus, the thicknesses of the effusion holes were $0.0125 \mathrm{~mm}$ and their areas and Clausing factors were as follows: hole $1, A_{0} / \mathrm{mm}^{2}=$ $0.6627, w_{\mathrm{o}}=0.9899$; hole $2, A_{\mathrm{o}} / \mathrm{mm}^{2}=0.7854, w_{\mathrm{o}}=0.9907$; hole $3, A_{\mathrm{o}} / \mathrm{mm}^{2}=0.9958, w_{\mathrm{o}}=0.9917$. In the Knudsen-2 apparatus, used for 3,3'-bithiophene, the areas and Clausing factors of the effusion orifices, made in platinum foil of 0.0125 $\mathrm{mm}$ thickness, are presented in Table S1 of the Supporting Information.

Computational Details. Standard ab initio molecular orbital calculations ${ }^{80}$ were performed with the Gaussian 03 series of programs. ${ }^{81}$ Energies were obtained using the Gaussian-3 theory, at the G3(MP2)//B3LYP level. ${ }^{82}$ This is a variation of G3(MP2) theory, ${ }^{83}$ that uses the B3LYP density functional method ${ }^{84}$ for geometries and zero-point energies. The B3LYP density functional used is a linear combination of Hartree-Fock exchange, Becke exchange, ${ }^{85}$ and Lee, Yang, and Parr (LYP) correlation. ${ }^{86}$

Two modifications have been made to derive G3(MP2)// B3LYP. First, the geometries are obtained at the B3LYP/6$31 \mathrm{G}(\mathrm{d})$ level instead of MP2(FULL)/6-31G(d). Second, the zeropoint energies are obtained at the B3LYP/6-31G(d) level and scaled by 0.960 instead of HF/6-31G(d) scaled by 0.893 . All of the other steps remain the same with the exception of the values of the higher-level correction parameters. ${ }^{82}$

G3(MP2)//B3LYP-calculated energies at $0 \mathrm{~K}$, and enthalpies at $298 \mathrm{~K}$, were calculated for all the species and confirmed as minima on the potential energy surface. Hybrid B3LYP calculations together with the $6-311+\mathrm{G}(2 \mathrm{~d}, 2 \mathrm{p})$ basis set, ${ }^{87}$ were also performed for comparison purposes. The two computational approaches have proven in the past to yield thermochemical data in very good agreement with experimental values. ${ }^{88-94} \mathrm{We}$ have also reoptimized the geometries at the MP2(full)/6$31 \mathrm{G}(3 \mathrm{df}, 2 \mathrm{p})$ level to obtain more reliable molecular structures for the compounds studied.

The charge distribution has been analyzed using a population partition technique, the natural bond orbital (NBO) analysis of Reed and Weinhold. ${ }^{95-97}$ The NBO analysis has been performed using the NBO program ${ }^{98}$ implemented in the Gaussian 03 package. $^{81}$
TABLE 1: Typical Combustion Results, at $T=298.15 \mathrm{~K}$ $\left(p^{\circ}=0.1 \mathrm{MPa}\right)$, for the Studied Compounds ${ }^{a}$

\begin{tabular}{lll}
\hline & $2,2^{\prime}$-bithiophene & $3,3^{\prime}$-bithiophene \\
\hline$m($ cpd $) / \mathrm{g}$ & 0.65634 & 0.54167 \\
$m^{\prime}($ fuse $) / \mathrm{g}$ & 0.00280 & 0.00280 \\
$m^{\prime \prime}(\mathrm{Melinex}) / \mathrm{g}$ & 0.03987 & \\
$T_{\mathrm{i}} / \mathrm{K}$ & 297.0161 & 297.2959 \\
$T_{\mathrm{f}} / \mathrm{K}$ & 298.1306 & 298.1881 \\
$\Delta T_{\mathrm{ad}} / \mathrm{K}$ & 1.08460 & 0.85740 \\
$\varepsilon_{\mathrm{I}} / \mathrm{J} \cdot \mathrm{K}^{-1}$ & 74.09 & 73.93 \\
$\varepsilon_{\mathrm{f}} / \mathrm{J} \cdot \mathrm{K}^{-1}$ & 72.87 & 72.70 \\
$\varepsilon_{\text {corr }} / \mathrm{J} \cdot \mathrm{K}^{-1}$ & 20373.18 & 20370.26 \\
$\Delta m\left(\mathrm{H}_{2} \mathrm{O}\right) / \mathrm{g}$ & 1.0 & 0.3 \\
$-\Delta U(\mathrm{IBP})^{b} / \mathrm{J}$ & 22176.08 & 17527.76 \\
$\Delta U(\mathrm{fuse}) / \mathrm{J}$ & 45.47 & 45.47 \\
$\Delta U(\mathrm{Melinex}) / \mathrm{J}$ & 913.10 & \\
$\left.\Delta U(\mathrm{HNO})_{3}\right) / \mathrm{J}$ & 35.28 & 21.55 \\
$\Delta U($ ign $) / \mathrm{J}$ & 1.09 & 1.08 \\
$\Delta U_{\Sigma} / \mathrm{J}$ & 21.58 & 18.90 \\
$-\Delta_{\mathrm{c}} u^{\circ} / \mathrm{J} \cdot \mathrm{g}^{-1}$ & 32240.38 & 32200.12 \\
${ }^{-1}(\mathrm{col})$ & &
\end{tabular}

${ }^{a} m(\mathrm{cpd})$ is the mass of compound burned in each experiment; $m^{\prime}$ (fuse) is the mass of the fuse (cotton) used in each experiment; $m^{\prime \prime}$ (Melinex) is the mass of Melinex used in each experiment; $T_{\mathrm{i}}$ is the initial temperature rise; $T_{\mathrm{f}}$ is the final temperature rise; $\Delta T_{\mathrm{ad}}$ is the corrected temperature rise; $\varepsilon_{\mathrm{i}}$ is the energy equivalent of the contents in the initial state; $\varepsilon_{\mathrm{f}}$ is the energy equivalent of the contents in the final state; $\varepsilon_{\text {corr }}$ is the energy equivalent of the calorimeter corrected for the deviation of mass of water added to the calorimeter; $\Delta m\left(\mathrm{H}_{2} \mathrm{O}\right)$ is the deviation of mass of water added to the calorimeter from $3965.0 \mathrm{~g} ; \Delta U(\mathrm{IBP})$ is the energy change for the isothermal combustion reaction under actual bomb conditions; $\Delta U$ (fuse) is the energy of combustion of the fuse (cotton); $\Delta U$ (Melinex) is the energy of combustion of the Melinex; $\Delta U\left(\mathrm{HNO}_{3}\right)$ is the energy correction for the nitric acid formation; $\Delta U$ (ign) is the electric energy for the ignition; $\Delta U_{\Sigma}$ is the standard state correction; $\Delta_{\mathrm{c}} u^{\circ}$ is the standard massic energy of combustion. ${ }^{b} \Delta U(\mathrm{IBP})$ includes $\Delta U$ (ignition).

\section{Results}

Rotating-Bomb Combustion Calorimetry. Table 1 lists the results of a single combustion experiment for each compound, in which $\Delta m\left(\mathrm{H}_{2} \mathrm{O}\right)$ represents the deviation of the mass of water added to the calorimeter from $3965.0 \mathrm{~g}$, the mass assigned to $\varepsilon$ (calor), and $\Delta U_{\Sigma}$, the correction to the standard state (Washburn corrections). The remaining symbols in Table 1 have been previously described. ${ }^{76,99}$

The internal energy for the isothermal bomb process, $\Delta U(\mathrm{IBP})$, was calculated according to eq 3

$$
\begin{aligned}
& \Delta U(\mathrm{IBP})=-\left\{\varepsilon \text { (calor) }+c_{\mathrm{p}}\left(\mathrm{H}_{2} \mathrm{O}, 1\right) \Delta m\left(\mathrm{H}_{2} \mathrm{O}\right)\right\} \Delta T_{\mathrm{ad}}+ \\
& \left(T_{\mathrm{i}}-298.15\right) \varepsilon_{\mathrm{i}}+\left(298.15-T_{\mathrm{i}}-\Delta T_{\mathrm{ad}}\right) \varepsilon_{\mathrm{f}}+\Delta U(\text { ign })
\end{aligned}
$$

where $\Delta T_{\text {ad }}$ is the calorimeter temperature change corrected for the heat exchange, the work of stirring, and the frictional work of bomb rotation (adiabatic temperature rise). Details of all the combustion calorimetry experiments, at $T=298.15 \mathrm{~K}$, for $2,2^{\prime}-$ bithiophene and 3,3'-bithiophene, respectively, are given as Supporting Information (Tables S2 and S3).

The individual values of $\Delta_{\mathrm{c}} u^{\circ}$ for each compound together with the respective mean value, $\left\langle\Delta_{\mathrm{c}} u^{\circ}\right\rangle$, and their standard deviations are presented in Table 2 . These values refer to the 
TABLE 2: Individual Values of Standard $\left(p^{\circ}=0.1 \mathrm{MPa}\right)$ Massic Energies of Combustion, $\Delta_{\mathrm{c}} u^{\circ}$, of the Compounds, at $T=298.15 \mathrm{~K}$

\begin{tabular}{|c|c|}
\hline 2,2'-bithiophene & 3,3'-bithiophene \\
\hline \multicolumn{2}{|c|}{$-\Delta_{\mathrm{c}} u^{\circ} / \mathrm{J} \cdot \mathrm{g}^{-1}$} \\
\hline 32235.19 & 32192.27 \\
\hline 32249.14 & 32206.13 \\
\hline 32238.34 & 32200.12 \\
\hline 32235.24 & 32206.98 \\
\hline 32240.38 & 32197.19 \\
\hline 32251.60 & 32203.13 \\
\hline \multicolumn{2}{|c|}{$-\left\langle\Delta_{\mathrm{c}} u^{\circ}\right\rangle /\left(\mathrm{J} \cdot \mathrm{g}^{-1}\right)$} \\
\hline$(32241.6 \pm 2.9)^{a}$ & $(32201.0 \pm 2.3)^{a}$ \\
\hline
\end{tabular}

${ }^{a}$ Mean value and standard deviation of the mean.

TABLE 3: Derived Standard $\left(p^{\circ}=0.1 \mathrm{MPa}\right)$ Molar Energies of Combustion, $\Delta_{\mathrm{c}} U_{\mathrm{m}}^{\circ}$, Standard Molar Enthalpies of Combustion, $\Delta_{\mathrm{c}} H_{\mathrm{m}}^{\circ}$, and Standard Molar Enthalpies of Formation, $\Delta_{\mathrm{f}} H_{\mathrm{m}}^{\circ}$, for the Crystalline Compounds, at $T=$ 298.15 K

\begin{tabular}{cccc}
\hline compound & $\begin{array}{c}-\Delta_{\mathrm{c}} U_{\mathrm{m}}^{\circ}(\mathrm{cr}) / \\
\mathrm{kJ} \cdot \mathrm{mol}^{-1}\end{array}$ & $\begin{array}{c}-\Delta_{\mathrm{c}} H_{\mathrm{m}}^{\circ}(\mathrm{cr}) / \\
\mathrm{kJ} \cdot \mathrm{mol}^{-1}\end{array}$ & $\begin{array}{c}\Delta_{\mathrm{f}} H_{\mathrm{m}}^{\circ}(\mathrm{cr}) / \\
\mathrm{kJ} \cdot \mathrm{mol}^{-1}\end{array}$ \\
\hline 2,2'-bithiophene & $5360.6 \pm 2.3$ & $5371.8 \pm 2.3$ & $162.3 \pm 2.7$ \\
3,3'-bithiophene & $5353.8 \pm 2.2$ & $5365.0 \pm 2.2$ & $155.5 \pm 2.6$
\end{tabular}

idealized combustion reaction represented by eq 4 for the two bithiophene isomers studied in this work

$$
\begin{array}{r}
\mathrm{C}_{8} \mathrm{H}_{6} \mathrm{~S}_{2}(\mathrm{cr})+12.5 \mathrm{O}_{2}(\mathrm{~g})+229 \mathrm{H}_{2} \mathrm{O}(\mathrm{l}) \rightarrow 8 \mathrm{CO}_{2}(\mathrm{~g})+ \\
2\left(\mathrm{H}_{2} \mathrm{SO}_{4} \cdot 115 \mathrm{H}_{2} \mathrm{O}\right)(\mathrm{l})
\end{array}
$$

The derived standard molar energies, $\Delta_{\mathrm{c}} U_{\mathrm{m}}^{\circ}(\mathrm{cr})$, and enthalpies of combustion, $\Delta_{\mathrm{c}} H_{\mathrm{m}}^{\circ}(\mathrm{cr})$, referred to the reaction described by eq 4, and the standard molar enthalpies of formation, in the crystalline phase, $\Delta_{\mathrm{f}} H_{\mathrm{m}}^{\circ}(\mathrm{cr})$, at $T=298.15 \mathrm{~K}$, are given in Table 3.

The uncertainties of the standard molar energies and enthalpies of combustion are twice the overall standard deviation of the mean and include the uncertainties in calibration and in the values of auxiliary quantities used. ${ }^{100,101}$

The standard molar enthalpies of formation of $\mathrm{H}_{2} \mathrm{SO}_{4}$ in 115 $\mathrm{H}_{2} \mathrm{O}(\mathrm{l}),-887.81 \pm 0.42 \mathrm{~kJ} \cdot \mathrm{mol}^{-1},{ }^{74} \mathrm{H}_{2} \mathrm{O}(\mathrm{l}),-285.830 \pm 0.042$ $\mathrm{kJ} \cdot \mathrm{mol}^{-1}$, and $\mathrm{CO}_{2}(\mathrm{~g}),-393.51 \pm 0.13 \mathrm{~kJ} \cdot \mathrm{mol}^{-1},{ }^{102}$ were used to derive $\Delta_{\mathrm{f}} H_{\mathrm{m}}^{\circ}(\mathrm{cr})$ of the two bithiophene isomers, at $T=298.15$ $\mathrm{K}$, from $\Delta_{\mathrm{c}} H_{\mathrm{m}}^{\circ}(\mathrm{cr})$.

Mass Loss Knudsen Technique. The standard molar enthalpies of sublimation, at the mean temperature of the experimental range, were calculated through the integrated form

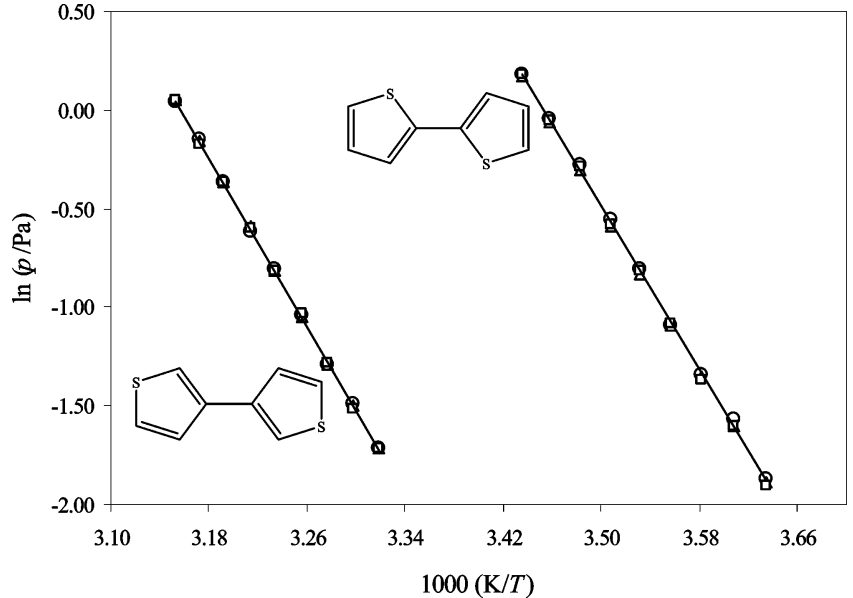

Figure 2. Plots of $\ln (p / \mathrm{Pa})$ against $1 / T$ for $3,3^{\prime}$-bithiophene and $2,2^{\prime}$ bithiophene: $\bigcirc$, small holes; $\triangle$, medium holes; $\square$, large holes.

of the Clausius-Clapeyron equation, $\ln (p / \mathrm{Pa})=a-b(K / T)$, where $a$ represents a constant and $b=\Delta_{\mathrm{cr}}^{\mathrm{g}} H_{\mathrm{m}}^{\circ}(\langle T\rangle) / R$. In Tables S4 and S5 of Supporting Information are summarized, for each effusion orifice used, the results of the vapor pressures obtained during the effusion time period $t$ at temperature $T$, together with the residuals of the Clausius-Clapeyron equation, derived from least-squares adjustment, for 2,2'-bithiophene and 3,3'-bithiophene, respectively. Table 4 presents, for each effusion orifice used and for the global treatment of all the $(p, T)$ points obtained for each bithiophene studied, the detailed parameters of the Clausius-Clapeyron equation, the respective standard deviations, and the standard molar enthalpies of sublimation at the mean temperature of the experiments, $\langle T\rangle$. The uncertainties associated with the enthalpies of sublimation were obtained from the standard deviation slopes of the least-squares fitting parameters of the experimental data (Tables S4 and S5 in Supporting Information) with the Clausius-Clapeyron equations, calculated by the SigmaPlot program, corresponding to a $95 \%$ confidence interval. The equilibrium pressure at the mean temperature, $p(\langle T\rangle)$ and the entropies of sublimation, at equilibrium conditions, relative to the global treatment are also listed. The entropies of sublimation, at equilibrium conditions, were calculated as

$$
\Delta_{\mathrm{cr}}^{\mathrm{g}} S_{\mathrm{m}}(\langle T\rangle, p(\langle T\rangle))=\Delta_{\mathrm{cr}}^{\mathrm{g}} H_{\mathrm{m}}^{\circ}(\langle T\rangle) /\langle T\rangle
$$

The plots of $\ln (p / \mathrm{Pa})$ against $1 / T$ for the global results obtained for the two studied compounds are shown in Figure 2.

Table 5 lists the $(p, T)$ values calculated from the $(p, T)$ equations for the crystalline title compounds, within the

\begin{tabular}{|c|c|c|c|c|c|c|}
\hline orifices & $a$ & $b$ & $\langle T\rangle / \mathrm{K}$ & $p(\langle T\rangle) / \mathrm{Pa}$ & $\Delta_{\mathrm{cr}}^{\mathrm{g}} H_{\mathrm{m}}^{\circ}(\langle T\rangle) / \mathrm{kJ} \cdot \mathrm{mol}^{-1}$ & $\Delta_{\mathrm{cr}}^{\mathrm{g}} S_{\mathrm{m}}(\langle T\rangle, p(\langle T\rangle)) / \mathrm{J} \cdot \mathrm{K}^{-1} \cdot \mathrm{mol}^{-1}$ \\
\hline \multicolumn{7}{|c|}{ 2,2'-bithiophene } \\
\hline hole 1 & $35.59 \pm 0.33$ & $10307 \pm 93$ & & & $85.7 \pm 0.8$ & \\
\hline hole 2 & $35.58 \pm 0.22$ & $10309 \pm 61$ & & & $85.7 \pm 0.5$ & \\
\hline hole 3 & $36.01 \pm 0.30$ & $10428 \pm 84$ & & & $86.7 \pm 0.7$ & \\
\hline global results & $35.73 \pm 0.18$ & $10348 \pm 50$ & 283.14 & 0.442 & $86.0 \pm 0.4$ & $303.7 \pm 1.4$ \\
\hline \multicolumn{7}{|c|}{ 3,3'-bithiophene } \\
\hline $\mathrm{A} 1-\mathrm{A} 2-\mathrm{A} 3$ & $33.50 \pm 0.17$ & $10611 \pm 51$ & & & $88.2 \pm 0.4$ & \\
\hline B4-B5-B6 & $33.78 \pm 0.17$ & $10698 \pm 53$ & & & $88.9 \pm 0.4$ & \\
\hline $\mathrm{C} 7-\mathrm{C} 8-\mathrm{C} 9$ & $33.67 \pm 0.30$ & $10665 \pm 92$ & & & $88.7 \pm 0.8$ & \\
\hline global results & $33.65 \pm 0.12$ & $10658 \pm 37$ & 309.22 & 0.442 & $88.6 \pm 0.3$ & $286.5 \pm 1.0$ \\
\hline
\end{tabular}

TABLE 4: Experimental Results for 2,2'-Bithiophene and 3,3'-Bithiophene, Where $a$ and $b$ are from the Clausius-Clapeyron Equation, $\ln (p / \mathrm{Pa})=a-b(\mathrm{~K} / T)$ and $b=\Delta_{\mathrm{cr}}^{\mathrm{g}} H_{\mathrm{m}}^{\circ}(\langle T\rangle) / R ; R=8.314472 \mathrm{~J} \cdot \mathrm{K}^{-1} \cdot \mathrm{mol}^{-1}$ 
TABLE 5: Calculated $(p, T)$ Values from the Vapor Pressure Equations for the Studied Compounds

\begin{tabular}{lcccccccccc}
\hline & \multicolumn{10}{c}{$T / \mathrm{K}$} \\
\cline { 2 - 9 } & $0.1 \mathrm{~Pa}$ & $0.2 \mathrm{~Pa}$ & $0.3 \mathrm{~Pa}$ & $0.4 \mathrm{~Pa}$ & $0.5 \mathrm{~Pa}$ & $0.6 \mathrm{~Pa}$ & $0.7 \mathrm{~Pa}$ & $0.8 \mathrm{~Pa}$ & $0.9 \mathrm{~Pa}$ & $1.0 \mathrm{~Pa}$ \\
\hline 2,2'-bithiophene & 272.1 & 277.1 & 280.2 & 282.4 & 284.1 & 285.5 & 286.8 & 287.8 & 288.8 & 289.6 \\
3,3'-bithiophene & 296.4 & 302.3 & 305.8 & 308.3 & 310.3 & 312.0 & 313.4 & 314.6 & 315.7 & 316.7
\end{tabular}

TABLE 6: Values of the Standard $\left(p^{\circ}=0.1 \mathrm{MPa}\right)$ Molar Enthalpies, $\Delta_{\mathrm{cr}}^{\mathrm{g}} H_{\mathrm{m}}^{\circ}$, Entropies, $\Delta_{\mathrm{cr}}^{\mathrm{g}} S_{\mathrm{m}}^{\circ}$, and Gibbs Energies $\Delta_{\mathrm{cr}}^{\mathrm{g}} G_{\mathrm{m}}^{\circ}$, of Sublimation, at $T=298.15 \mathrm{~K}$, for the Studied Compounds

\begin{tabular}{cccc}
\hline compound & $\begin{array}{c}\Delta_{\mathrm{cr}}^{\mathrm{g}} H_{\mathrm{m}}^{\circ} / \\
\mathrm{kJ} \cdot \mathrm{mol}^{-1}\end{array}$ & $\begin{array}{c}\Delta_{\mathrm{c}}^{\mathrm{g}} S_{\mathrm{m}}^{\circ} / \\
\mathrm{J} \cdot \mathrm{K}^{-1} \cdot \mathrm{mol}^{-1}\end{array}$ & $\begin{array}{c}\Delta_{\mathrm{cr}}^{\mathrm{g}} G_{\mathrm{m}}^{\circ} / \\
\mathrm{kJ} \cdot \mathrm{mol}^{-1}\end{array}$ \\
\hline 2,2'-bithiophene & $85.2 \pm 0.4$ & $198.6 \pm 1.4$ & $26.0 \pm 0.6$ \\
3,3'-bithiophene & $89.2 \pm 0.3$ & $185.8 \pm 1.0$ & $33.8 \pm 0.4$
\end{tabular}

TABLE 7: Standard ( $\left.p^{\circ}=0.1 \mathrm{MPa}\right)$ Molar Enthalpies of Formation, in Both Crystalline and Gaseous Phases, and Standard Molar Enthalpies of Sublimation, at $\boldsymbol{T}=298.15 \mathrm{~K}$

\begin{tabular}{cccc}
\hline compound & $\begin{array}{c}\left.\Delta_{\mathrm{f}} H_{\mathrm{m}}^{\circ}(\mathrm{cr})\right) / \\
\left(\mathrm{kJ} \cdot \mathrm{mol}^{-1}\right)\end{array}$ & $\begin{array}{c}\Delta_{\mathrm{cr}}^{\mathrm{g}} H_{\mathrm{m}}^{\circ} / \\
\mathrm{kJ} \cdot \mathrm{mol}^{-1}\end{array}$ & $\begin{array}{c}\Delta_{\mathrm{f}} H_{\mathrm{m}}^{\circ}(\mathrm{g}) / \\
\mathrm{kJ} \cdot \mathrm{mol}^{-1}\end{array}$ \\
\hline 2,2'-bithiophene & $162.3 \pm 2.7$ & $85.2 \pm 0.4$ & $247.5 \pm 2.7$ \\
3,3'-bithiophene & $155.5 \pm 2.6$ & $89.2 \pm 0.3$ & $244.7 \pm 2.6$
\end{tabular}

experimental range of pressures used $(0.1-1.0 \mathrm{~Pa})$. The enthalpies of sublimation, at $T=298.15 \mathrm{~K}$, were derived through eq 6 , from the enthalpies of sublimation, at the mean temperature, $\langle T\rangle$, of the experiment

$$
\begin{aligned}
\Delta_{\mathrm{cr}}^{\mathrm{g}} H_{\mathrm{m}}^{\circ}(T=298.15 \mathrm{~K})=\Delta_{\mathrm{cr}}^{\mathrm{g}} H_{\mathrm{m}}^{\circ}(\langle T\rangle)+ \\
\Delta_{\mathrm{cr}}^{\mathrm{g}} C_{\mathrm{p}, \mathrm{m}}^{\circ}(298.15-\langle T\rangle)
\end{aligned}
$$

For each compound studied, the value $\Delta_{\mathrm{cr}}^{\mathrm{g}} C_{\mathrm{p}, \mathrm{m}}^{\circ}=-50$ $\mathrm{J} \cdot \mathrm{K}^{-1} \cdot \mathrm{mol}^{-1}$ was assumed, in harmony with similar estimations made by Burkinshaw and Mortimer, ${ }^{103}$ which we have already used in previous papers where other organic compounds were studied. ${ }^{48,53,54,104,105}$

The standard molar enthalpies, $\Delta_{\mathrm{cr}}^{\mathrm{g}} H_{\mathrm{m}}^{\circ}$, entropies, $\Delta_{\mathrm{cr}}^{\mathrm{g}} S_{\mathrm{m}}^{\circ}$, and Gibbs energies of sublimation, $\Delta_{\mathrm{cr}}^{\mathrm{g}} G_{\mathrm{m}}^{\circ}$, at $T=298.15 \mathrm{~K}$, are presented in Table 6.

Experimental Gas-phase Enthalpies of Formation. The standard molar enthalpies of formation in the gaseous phase, at $T=298.15 \mathrm{~K}$, for the title compounds studied experimentally, derived from the respective standard molar enthalpies of formation in crystalline phase and the standard molar enthalpies of sublimation, given in Tables 3 and 6, respectively, are summarized in Table 7.

Considering the experimental data reported in Table 7 , it is shown in Figure 3 that 2,2'- and 3,3'-bithiophenes are, within the associated uncertainties, enthalpically similar, with an isomerization enthalpy of only $-2.8 \pm 3.7 \mathrm{~kJ} \cdot \mathrm{mol}^{-1}$. Furthermore, making use of the literature value of the standard molar enthalpy of formation, in the gaseous phase, of thiophene,

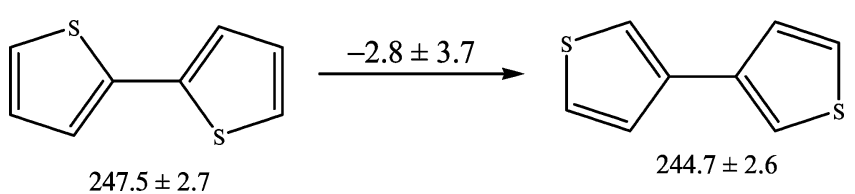

Figure 3. Enthalpic increment for the isomerization of 2,2'-bithiophene to $3,3^{\prime}$-bithiophene.
$\Delta_{\mathrm{f}} H_{\mathrm{m}}^{\circ}\left(\mathrm{C}_{4} \mathrm{H}_{4} \mathrm{~S}, \mathrm{~g}\right)=115.0 \pm 1.0 \mathrm{~kJ} \cdot \mathrm{mol}^{-1},{ }^{106}$ we calculate the enthalpic increments for the introduction of a thienyl group in positions 2 and 3 of the thiophene ring as $132.5 \pm 2.9 \mathrm{~kJ} \cdot \mathrm{mol}^{-1}$ and $129.7 \pm 2.8 \mathrm{~kJ} \cdot \mathrm{mol}^{-1}$, respectively (Figure 4).

Molecular and Electronic Structures. The conformational behavior of 2,2'-bithiophene has been widely investigated both experimentally and theoretically and, thus, only the most important available results will be summarized here (see Supporting Information for an extensive review of literature data). Previous experimental studies show that the most stable configurations for this compound in the gas phase are the nonplanar s-trans (twist angles, $\phi$, of $146^{\circ}$ to $159^{\circ}$ ) and s-cis conformations $\left(\phi\right.$ is $\sim 36^{\circ}$ ). In solution, a nonplanar s-trans conformation with $\phi$ between $140^{\circ}$ and $150^{\circ}$ was proposed and a planar s-trans conformation $\left(\phi\right.$ is $\left.180^{\circ}\right)$ was suggested for this compound in the solid state. The s-trans conformation (56 \pm $4 \%)$ is more abundant than the s-cis $(44 \pm 4 \%)$. Previous computational studies suggest stable s-trans $\left(\phi\right.$ is $\left.\sim 150^{\circ}\right)$ and s-cis $\left(\phi\right.$ is $\sim 40^{\circ}$ ) conformations and the former conformation is the most abundant $(70 \pm 5 \%)$.

The molecular structures of the syn-gauche and antigauche rotamers of 2,2'-, 2,3'-, and 3,3'-bithiophenes, optimized in this work at the MP2(Full)/6-31G(3df,2p) level of theory, are shown in Figures 5 and 6. Calculated bond distances and angles are collected in the Supporting Information (Tables S6-S8), and compared with experimental values when available. The optimized structures of both rotamers for each species are practically identical, the only difference being the torsional angle about the inter-ring $\mathrm{C}-\mathrm{C}$ bond.

It is found a very good agreement between the optimized structures of 2,2'-bithiophene, both syn-gauche and antigauche rotamers, and the experimental gas-phase electron diffraction structures. ${ }^{38,39}$ There is also a good agreement between the optimized structures of the rings for 2,2'- and 3,3'-bithiophenes and the experimental X-ray diffraction structures (planar molecules are found in the solid phase) ${ }^{61}$ Importantly, it has also to be noted the very good agreement between the calculated and experimental twist angles of both syn-gauche and antigauche rotamers for 2,2'- and 3,3'-bithiophenes.

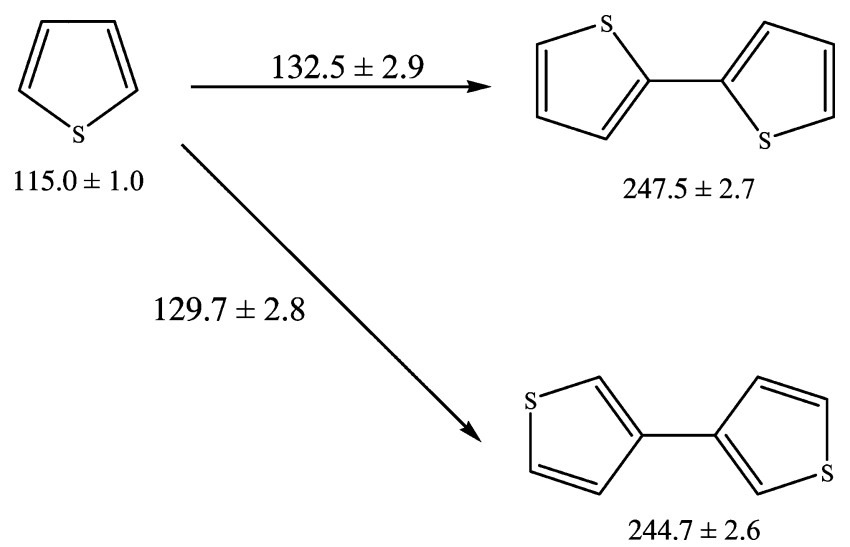

Figure 4. Enthalpic increment for the introduction of a thienyl group into positions 2 and 3 of thiophene. 

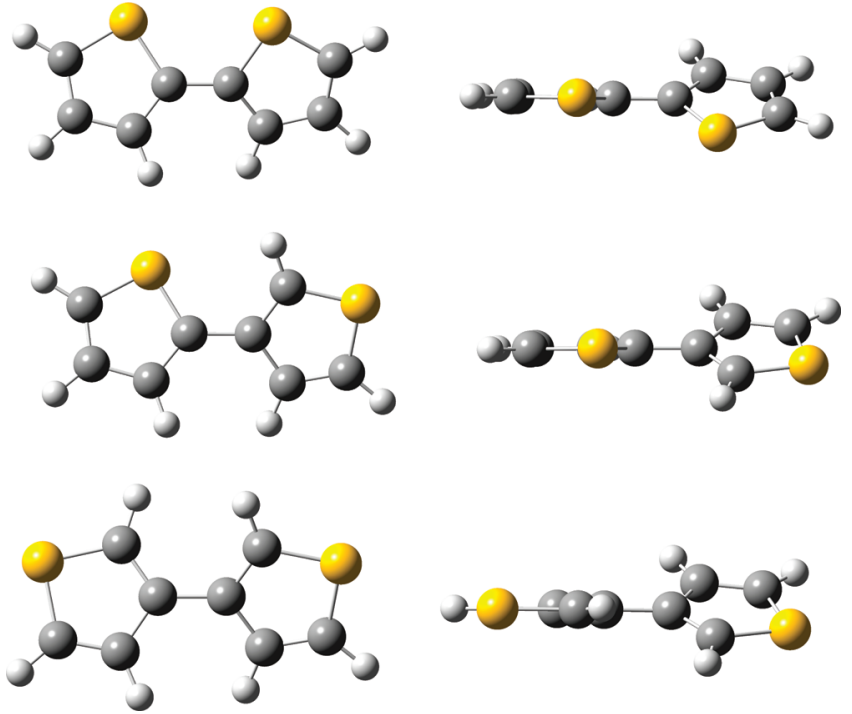

Figure 5. Front and side views of the MP2(FULL)/6-31G(3df,2p)optimized structures of the syn-gauche conformers of 2,2'-, 2,3'-, and 3,3'-bithiophenes.
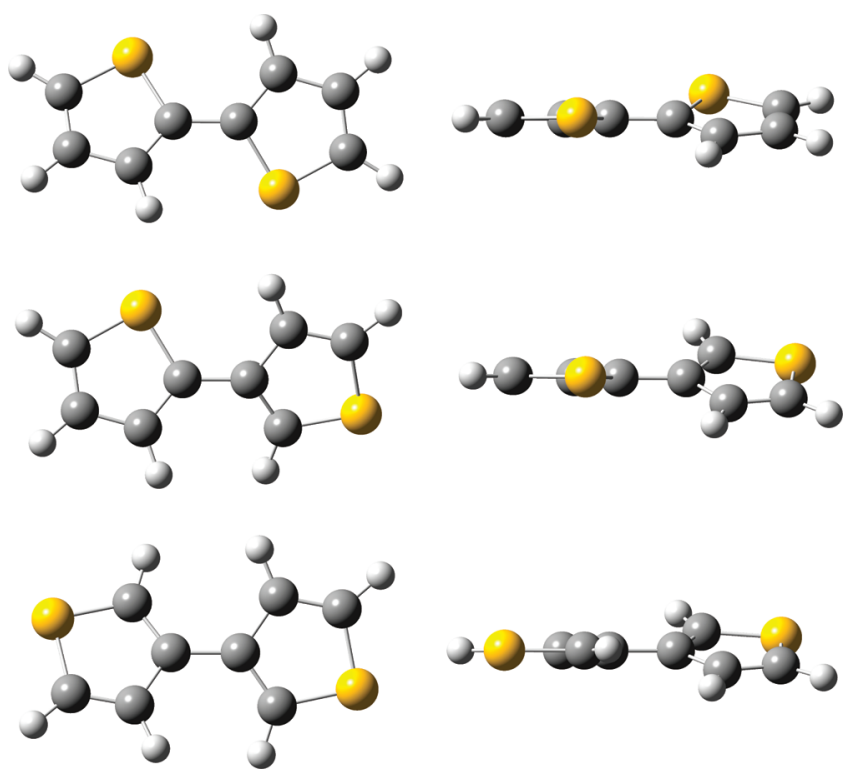

Figure 6. Front and side views of the MP2(FULL)/6-31G(3df,2p)optimized structures of the antigauche conformers of $2,2^{\prime}-, 2,3^{\prime}-$, and 3,3'-bithiophenes.
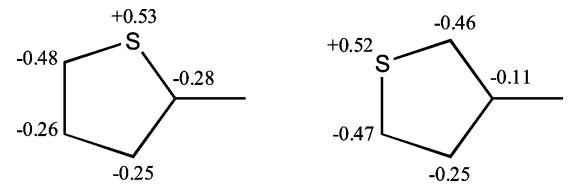

Figure 7. Average NBO charges at the heavy atoms of the two type of rings in bithiophenes.

A population analysis using the natural bond orbital (NBO) analysis, ${ }^{95-97}$ has also been carried out. The calculated charges located at the heavy atoms for both type of rings are reported in Figure 7. Partial negative charges are located at the carbon atoms of the thiophene rings, whereas partial positive charges are located at the sulfur atom of the rings. The charge distribution does not appreciably change with the position of the $\mathrm{S}$ atom in the ring, only a small negative charge redistribution takes place on the $\mathrm{C}$ atoms of the thiophene ring.
Theoretical Determination of Gas-Phase Enthalpies of Formation. G3(MP2)//B3LYP calculated energies at $0 \mathrm{~K}$, and enthalpies at $298 \mathrm{~K}$, for the two minima, syn-gauche and antigauche, conformers of 2,2'-, 2,3'-, and 3,3'-bithiophenes are given in Table S9 (Supporting Information). Antigauche is the most stable rotamer in 2,2'-bithiophene and in 3,3'-bithiophene, whereas syn-gauche is the most stable rotamer in 2,3'bithiophene, the energy differences between rotamers are also given in Table S9 in Supporting Information. The calculated differences between rotamers are $1.5,0.6$, and $0.9 \mathrm{~kJ} \cdot \mathrm{mol}^{-1}$ for 2,2'-, 2,3'-, and 3,3'-bithiophenes, respectively.

In this work we have calculated the enthalpies of formation of the two rotamers of bithiophenes using the atomization reaction and the following isodesmic reaction:

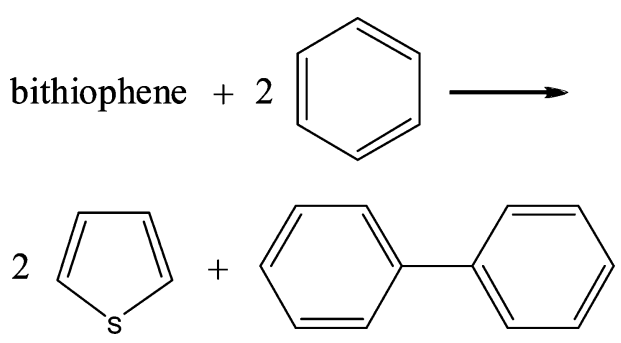

The G3(MP2)//B3LYP calculated enthalpies of formation using atomization and isodesmic reactions are shown in Table 8. ${ }^{106,107}$ Due to the accumulation of errors in large molecules with double bonds, the values calculated with the atomization reaction may be improved if a bond additivity correction (BAC) is done. ${ }^{108}$

The BAC-corrected values (Table 8) are now similar to the values obtained with the isodesmic reaction and are close to the experimental ones.

The conformational composition of each bithiophene in the gas phase at $T=298.15 \mathrm{~K}$ was calculated from the $\Delta_{\mathrm{f}} G_{\mathrm{m}}^{\circ}$ values through eq 8

$$
\Delta_{\mathrm{f}} G_{\mathrm{m}}^{\circ}(i)=\Delta_{\mathrm{f}} H_{\mathrm{m}}^{\circ}(i)-T\left[S^{\circ}(i)-\sum S^{\circ}(\mathrm{el})\right]
$$

where the sum of the entropy of the elements, in the case of the compound studied, is calculated as

$$
\sum S^{\circ}(\mathrm{el})=8 S^{\circ}(\mathrm{C}, \mathrm{s})+3 S^{\circ}\left(\mathrm{H}_{2}, \mathrm{~g}\right)+2 S^{\circ}(\mathrm{S}, \mathrm{s})
$$

Using for the elements the entropy values, at $T=298.15 \mathrm{~K}$, taken from ref $109, \Delta_{\mathrm{f}} G_{\mathrm{m}}^{\circ}$ values have been obtained for all the conformers and collected in Table 9.

Using eq 10

$$
x_{i}=\frac{\mathrm{e}^{-\Delta_{\mathrm{f}} G_{\mathrm{m}}^{\circ}(i) / R T}}{\sum_{i=1}^{n} \mathrm{e}^{-\Delta_{\mathrm{f}} G_{\mathrm{m}}^{\circ}(i) / R T}}
$$

we have obtained the composition in the gas phase at $T=298.15$ $\mathrm{K}$ for the three bithiophenes (Table 9). The calculated compositions agree very well with the available experimental data. 
TABLE 8: G3(MP2)//B3LYP Calculated Enthalpies of Formation, $\Delta_{\mathrm{f}} H_{\mathrm{m}}^{\circ}(\mathrm{g})$, Using Atomization and Isodesmic Reactions for the Two Stable Rotamers of Bithiophenes, Values in $\mathbf{k J} \cdot \mathbf{m o l}^{-1}$

\begin{tabular}{|c|c|c|c|c|c|}
\hline compound & rotamer & atomization $^{a}$ & isodesmic & mean value ${ }^{b}$ & $\Delta \Delta_{\mathrm{f}} H_{\mathrm{m}}^{\circ}(\mathrm{g})$ \\
\hline \multirow[t]{2}{*}{ 2,2'-bithiophene } & syn-gauche & $220.7(248.0)$ & 246.9 & 247.45 & 1.55 \\
\hline & antigauche & $219.2(246.5)$ & $245.3^{c}$ & 245.9 & 0.0 \\
\hline \multirow[t]{2}{*}{ 2,3'-bithiophene } & syn-gauche & $219.6(246.9)$ & $245.8^{c}$ & 246.35 & 0.0 \\
\hline & antigauche & $220.3(247.5)$ & 246.4 & 246.95 & 0.6 \\
\hline \multirow[t]{2}{*}{ 3,3'-bithiophene } & syn-gauche & $221.5(249.3)$ & 247.7 & 248.5 & 0.85 \\
\hline & antigauche & $220.7(248.5)$ & $246.8^{c}$ & 247.65 & 0.0 \\
\hline
\end{tabular}

${ }^{a}$ In parentheses the BAC corrected values. See text. ${ }^{b}$ Mean value from the values calculated using atomization and isodesmic reactions. ${ }^{c} \mathrm{~B} 3 \mathrm{LYP} / 6-311+\mathrm{G}(2 \mathrm{~d}, 2 \mathrm{p})$ enthalpies of formation for the most stable rotamers are 239.6, 241.3, and $242.9 \mathrm{~kJ}^{\mathrm{mol}}{ }^{-1}$ for $2,2^{\prime}-, 2^{2}, 3^{\prime}-$, and 3,3'-bithiophenes, respectively.

TABLE 9: Calculated Gibbs Energies of Formation, Percentages of Each Rotamer, and Enthalpies of Formation of Bithiophenes, Energy Values in $\mathrm{kJ} \cdot \mathrm{mol}^{-1}$

\begin{tabular}{|c|c|c|c|c|c|c|}
\hline \multirow[b]{2}{*}{ compound } & \multirow[b]{2}{*}{ rotamer } & \multirow[b]{2}{*}{$\Delta_{\mathrm{f}} G_{\mathrm{m}}^{\circ}$} & \multicolumn{2}{|c|}{$\%$} & \multicolumn{2}{|c|}{$\Delta_{\mathrm{f}} H_{\mathrm{m}}^{\circ}(\mathrm{g})$} \\
\hline & & & calcd & exptl & calcd & exptl \\
\hline 2,2'-bithiophene & syn-gauche & 281.5 & 31.4 & $\begin{array}{l}30 \pm 5^{a} \\
44 \pm 4^{b}\end{array}$ & 246.4 & $247.5 \pm 2.7$ \\
\hline & antigauche & 279.5 & 68.6 & $\begin{array}{l}70 \pm 5^{a} \\
56 \pm 4^{b}\end{array}$ & & \\
\hline 2,3'-bithiophene & $\begin{array}{l}\text { syn-gauche } \\
\text { antigauche }\end{array}$ & $\begin{array}{l}280.3 \\
281.0\end{array}$ & $\begin{array}{l}57.2 \\
42.8\end{array}$ & & 246.6 & \\
\hline 3,3'-bithiophene & $\begin{array}{l}\text { syn-gauche } \\
\text { antigauche }\end{array}$ & $\begin{array}{l}284.7 \\
283.6\end{array}$ & $\begin{array}{l}38.1 \\
61.9\end{array}$ & $\begin{array}{l}\sim 40^{c} \\
\sim 60^{c}\end{array}$ & 248.0 & $244.7 \pm 2.6$ \\
\hline
\end{tabular}

${ }^{a}$ Value obtained from a NMR study of 2,2'-bithiophene partially oriented in the nematic phase of a liquid crystalline solvent, taken from ref 43. ${ }^{b}$ Value obtained from an electron diffraction study of $2,2^{\prime}$-bithiophene, taken from ref $39 .{ }^{c}$ Value obtained from an electron diffraction study of $3,3^{\prime}$-bithiophene, taken from ref 111 .

Furthermore, using eq 11

$$
\Delta_{\mathrm{f}} H_{\mathrm{m}}^{\circ}(X)=\sum_{i=1}^{n} x_{i} \Delta_{\mathrm{f}} H_{\mathrm{m}}^{\circ}(i)
$$

the final values for the enthalpies of formation of $2,2^{\prime}-, 2,3^{\prime}-$, and 3,3'-bithiophenes have been obtained. As observed in Table 9 , the calculated enthalpies of formation are in very good agreement with the experimental values determined in this work.

Additionally, the bond dissociation enthalpies (BDE) of the inter-ring $\mathrm{C}-\mathrm{C}$ bond for the three bithiophenes were calculated through reactions

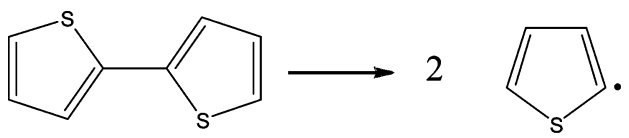<smiles>Cc1cc(-c2cccs2)cs1</smiles><smiles>c1csc(-c2cccs2)c1</smiles><smiles>c1cc(-c2ccsc2)cs1</smiles>

Values are $549.3,539.0$, and $528.0 \mathrm{~kJ} \cdot \mathrm{mol}^{-1}$ for $2,2^{\prime}-, 2,3^{\prime}-$, and 3,3'-bithiophene, respectively. From reactions 12 and 14 and using the calculated enthalpies of formation of $2,2^{\prime}$ - and $3,3^{\prime}$-bithiophenes, the calculated enthalpies of formation of 2- and 3-thienyl radicals are 397.9 and $388.0 \mathrm{~kJ} \cdot \mathrm{mol}^{-1}$, respectively.
From the BDE of 2,3'-bithiophene and the enthalpies of formation of thienyl radicals, we can calculate a value of 246.9 $\mathrm{kJ} \cdot \mathrm{mol}^{-1}$ for the enthalpy of formation of 2,3'-bithiophene, which is in very good agreement with the value calculated from atomization and isodesmic reactions, $246.6 \mathrm{~kJ} \cdot \mathrm{mol}^{-1}$.

The calculated enthalpies of formation of thienyl radicals can be compared with those obtained from the homolytic bond dissociation enthalpies, BDEs, of the $\mathrm{C}-\mathrm{H}$ bonds in thiophene<smiles>Cc1cccs1</smiles><smiles>c1ccsc1</smiles>

From reactions 15 and 16 , values of 496.5 and $486.6 \mathrm{~kJ} \cdot \mathrm{mol}^{-1}$ have been calculated for the $\mathrm{C}-\mathrm{H}$ BDEs of thiophene in 2and 3-positions, respectively, indicating that hydrogen atom loss from position 3 is favored over that from position 2 by 9.9 $\mathrm{kJ} \cdot \mathrm{mol}^{-1}$. These values agree with those calculated at different CBS levels by Barckholtz et al. ${ }^{110}$ From them and the experimental enthalpies of formation of thiophene ${ }^{106}$ and hydrogen atom, ${ }^{109}$ values of 393.5 and $383.6 \mathrm{~kJ} \cdot \mathrm{mol}^{-1}$ have been obtained for the enthalpies of formation of 2- and 3-thienyl radicals, respectively, again in good agreement with the values calculated above.

\section{Conclusions}

A combined experimental and computational study was entailed aiming at the determination of the molecular structure 
and stability of the 2,2'-, 2,3'-, and 3,3'-bithiophenes and corresponding thienyl radicals. When possible (availability of experimental data that is lacking for 2,3'-bithiophene), the agreement between computer or laboratory determined enthalpies of formation and molecular structures is very good, which supports the following conclusions. It is found that the structure of the three possible bithiophenes is not planar with a noticeable rotation around the $\operatorname{ring}(\mathrm{C})-(\mathrm{C})$ ring bonds. From several different schemes used to calculate the enthalpies of formation of the compounds, it is found that an antigauche conformation is more stable in the case of the 2,2' - and 3,3'-bithiophenes while the syn-gauche rotamer is more stable than the antigauche in the case of 2,3'-bithiophene. Importantly, the enthalpic differences between different isomers and between different rotamers are very small and the compounds are almost degenerate. The differences are smaller than $2.4 \mathrm{~kJ} \cdot \mathrm{mol}^{-1}$.

Acknowledgment. Thanks are due to Fundação para a Ciência e Tecnologia (FCT), Lisbon, Portugal, and to FEDER for financial support to Centro de Investigação em Química, University of Porto. A.F.L.O.M.S. and J.R.B.G. thank FCT and the European Social Fund (ESF) under the Community Support Framework (CSF) for the award of a PhD research grant (SFRH/ $\mathrm{BD} / 12886 / 2003)$ and a postdoc (BPD/11582/2002) research scholarship, respectively. We acknowledge the support of the Spanish MEC/DGI under projects CTQU2006-1078/BQU and CTQ2007-60895/BQU. M.T. would like to thank MEC/SEUI, FPU AP 2002-0603, Spain for financial support.

Supporting Information Available: A table presenting the exact areas and transmission probability factors for the platinum orifices of the Knudsen-2 effusion apparatus, used for the study of 3,3'-bithiophene, tables listing the details of all the combustion calorimetry experiments, at $T=298.15 \mathrm{~K}$, for $2,2^{\prime}$ - and $3,3^{\prime}$-bithiophenes, tables with the Knudsen effusion results for $2,2^{\prime}$ - and 3,3'-bithiophenes, a review of experimental and computational structures of the bithiophenes, tables with the MP2(FULL)/6-31G(3df,2p) calculated bond lengths and bond angles for 2,2'-, 2,3'-, and 3,3'-bithiophenes, table with the G3(MP2)//B3LYP energies at $0 \mathrm{~K}$ and enthalpies at $298 \mathrm{~K}$ for the bithiophenes and thienyl radicals, and tables with B3LYP/ $6-311+\mathrm{G}(2 \mathrm{~d}, 2 \mathrm{p})$ enthalpies at $298 \mathrm{~K}$. This material is available free of charge via the Internet at http://pubs.acs.org.

\section{References and Notes}

(1) Hotta, S. In Handbook of Organic Conductive Molecules and Polymers; Nalwa, H. S., Ed.; Wiley: Chichester, 1997; Vol. 2, Chapter 8.

(2) Bäuerle, P. In Electronic Materials: The Oligomer Approach; Müllen, K., Wegner, G., Eds.; Wiley: New York, 1998; pp 105-197.

(3) Cornil, J.; Beljonne, D.; Brédas, J. L. In Electronic Materials: The Oligomer Approach, Müllen, K., Wegner, G., Eds.; Wiley: New York, 1998; pp 432-447.

(4) Handbook of Oligo-and Polythiophenes; Fichou, D., Ed.; WileyVCH: Weinheim, 1999.

(5) Viruela, P. M.; Viruela, R.; Ortí, E. Int. J. Quantum Chem. 1998, 70, 303-312.

(6) McCullough, R. D. Adv. Mater. 1998, 10, 93-116.

(7) Roncali, J. Chem. Rev. 1992, 92, 711-738.

(8) Tourillon G. Handbook of Conducting Polymers; Skotheim, T. A., Ed.; Marcel Dekker: New York, 1986; pp 293-350.

(9) Roncali, J. Chem. Rev. 1997, 97, 173-205.

(10) Perepichka, I. F.; Perepichka, D. F.; Meng, H.; Wudl, F. Adv. Mater. 2005, 17, 2281-2305.

(11) Barbarella, G.; Melucci, M; Sotgiu, G. Adv. Mater. 2005, 17, $1581-1593$

(12) Mazzeo, M.; Vitale, V.; Della Sala, F.; Pisignano, D.; Anni, M.; Barbarella, G.; Favaretto, L.; Zanelli, A.; Cingolani, R.; Gigli, G. Adv. Mater. 2003, 15, 2060-2063.

(13) Huang, W.; Meng, H.; Yu, W. -L.; Gao, J.; Heeger, A. J. Adv. Mater. 1998, 10, 593-596.
(14) Barta, P.; Sanetra, J.; Zagórska, M. Synth. Met. 1998, 94, 119121.

(15) Cheylan, S.; Fraleoni-Morgera, A.; Puigdollers, J.; Voz, C.; Setti, L.; Alcubilla, R.; Badenes, G.; Costa-Bizarri, P.; Lanzi, M. Thin Solid Films 2006, 497, 16-19.

(16) Sirringhaus, H.; Tessler, N.; Friend, R. H. Science 1998, 280 , $1741-1744$.

(17) Fichou, D. J. Mater. Chem. 2000, 10, 571-588.

(18) Garnier, F.; Horowitz, G.; Peng, X.; Fichou, D. Adv. Mater. 1990, $2,592-594$.

(19) Rost, C.; Karg, S.; Riess, W. Appl. Phys. Lett. 2004, 85, 16131615.

(20) Rost, H.; Ficker, J.; Alonso, J. S.; Lenders, L.; McCulloch, I. Synth. Met. 2004, 145, 83-85.

(21) Porzio, W.; Destri, S.; Giovanella, U.; Pasini, M.; Motta, T.; Natali, D.; Sampietro, M.; Campione, M. Thin Solid Films 2005, 492, 212-220.

(22) Crouch, D. J.; Skabara, P. J.; Lohr, J. E.; McDouall, J. J. W.; Heeney, M.; McCulloch, I.; Sparrowe, D.; Shkunov, M.; Coles, S. J.; Horton, P. N.; Hursthouse, M. B. Chem. Mater. 2005, 17, 6567-6578.

(23) Nguyen, P. T.; Rammelt, U.; Plieth, W.; Richter, S.; Plötner, M.; Fischer, W. -J.; Kiriy, N.; Kamloth, K. P.; Adler, H. -J. Electrochim. Acta 2005, 50, 1757-1763.

(24) Garnier, F.; Hajlaoui, R.; Yassar, A.; Srivastava, P. Science 1994, $265,1684-1686$. 271.

(25) Dodabalapur, A.; Torsi, L.; Katz, H. E. Science 1995, 268, 270-

(26) Sirringhaus, H.; Kawase, T.; Friend, R. H.; Shimoda, T.; Inbasekaran, M.; Wu, W.; Woo, E. P. Science 2000, 290, 2123-2126.

(27) Dimitrakopoulos, C. D.; Malenfant, P. R. L. Adv. Mater. 2002, 14, 99-117.

(28) Pappenfus, T. M.; Chesterfield, R. J.; Frisbie, C. D.; Mann, K. R.; Casado, J.; Raff, J. D.; Miller, L. L. J. Am. Chem. Soc. 2002, 124, 41844185.

(29) Halik, M.; Klauk, H.; Zschieschang, U. Adv. Mater. 2003, 15, 917-922.

(30) Ling, M. M.; Bao, Z. Chem. Mater. 2004, 16, 4824-4840.

(31) Casado, J; Pappenfus, T. M.; Miller, L. L.; Mann, K. R.; Ortí, E.; Viruela, P. M.; Pou-AméRigo, R.; Hernández, V.; López-Navarrete, J. T. J. Am. Chem. Soc. 2003, 125, 2524-2534.

(32) Tour, J. M. Acc. Chem. Res. 2000, 33, 791-804.

(33) Novák, P.; Müller, K.; Santhanam, K. S. V.; Haas, O. Chem. Rev. 1997, 97, 207-281.

(34) Giannetto, M.; Mastria, V.; Mori, G.; Arduini, A.; Secchi, A. Sens. Actuators, B 2006, 115, 62-68.

(35) Kunugi, Y.; Miller, L. L.; Mann, K. R.; Pomije, M. K. Chem. Mater. 1998, 10, 1487-1489.

(36) Béra-Abérem, M.; Ho, H.-A.; Leclerc, M. Tetrahedron 2004, 60, $11169-11173$.

(37) Doré, K.; Dubus, S.; Ho, H. -A.; Lévesque, I.; Brunette, M.; Corbeil, G.; Boissinot, M.; Boivin, G.; Bergeron, M. G.; Boudreau, D.; Leclerc, M. J. Am. Chem. Soc. 2004, 126, 4240-4244.

(38) Almenningen, A.; Bastiansen, O.; Svendsås, P. Acta Chem. Scand. 1958, 12, 1671-1674.

(39) Samdal, S.; Samuelsen, E. J.; Volden, H. V. Synth. Met. 1993, 59, 259-265.

(40) Pelletier, M.; Brisse, F. Acta Crystallogr. C 1994, 50, 1942-1945.

(41) Wynberg, H. Angew. Chem. 1963, 75, 453-453.

(42) Lumbroso, H.; Carpanelli, C. Bull Soc. Chim. Fr. 1964, 31983198.

(43) Bucci, P.; Longeri, M.; Veracini, C. A.; Lunazzi, L. J. Am. Chem. Soc. 1974, 96, 1305-1309.

(44) Raos, G.; Famulari, A.; Marcon, V. Chem. Phys. Lett. 2003, 379, 364-372.

(45) Ribeiro da Silva, M. A. V.; Santos, A. F. L. O. M. J. Therm. Anal. Calorim. 2007, 88, 7-17.

(46) Roux, M. V.; Temprado, M.; Notario, R.; Chickos, J. S.; Santos, A. F. L. O. M.; Ribeiro da Silva, M. A. V. J. Phys. Chem. A 2007, 111, $5280-5286$.

(47) Roux, M. V.; Temprado, M.; Jiménez, P.; Notario, R.; Chickos, J. S.; Santos, A. F. L. O. M.; Ribeiro da Silva, M. A. V. J. Phys. Chem. A 2007, 111, 11084-11092.

(48) Ribeiro da Silva, M. A. V.; Santos, A. F. L. O. M. J. Chem. Thermodyn. 2008, 40, 166-173.

(49) Ribeiro da Silva, M. A. V.; Santos, A. F. L. O. M. J. Chem. Thermodyn. 2008, 40, 225-231.

(50) Ribeiro da Silva, M. A. V.; Santos, A. F. L. O. M. J. Chem. Thermodyn. 2008, 40, 917-923.

(51) Ribeiro da Silva, M. A. V.; Santos, A. F. L. O. M. J. Chem. Thermodyn. 2008, 40, 1217-1221.

(52) Ribeiro da Silva, M. A. V.; Santos, A. F. L. O. M. J. Chem. Thermodyn. 2008, 40, 1309-1313.

(53) Ribeiro da Silva, M. A. V.; Santos, A. F. L. O. M. J. Chem. Thermodyn. 2008, 40, 1451-1457. 
(54) Ribeiro da Silva, M. A. V.; Amaral, L. M. P. F.; Santos, A. F. L. O. M. J. Chem. Thermodyn. 2008, 40, 1588-1593.

(55) Ribeiro da Silva, M. A. V.; Santos, A. F. L. O. M. J. Therm. Anal. Calorim. 2009, 95, 333-344.

(56) Temprado, M.; Roux, M. V.; Jiménez, P.; Dávalos, J. Z.; Notario, R. J. Phys. Chem. A 2002, 106, 11173-11180.

(57) Roux, M. V.; Temprado, M.; Jiménez, P; Dávalos, J. Z.; FocesFoces, C.; García, M. V.; Redondo, M. I. Thermochim. Acta 2003, 404, $235-244$.

(58) Roux, M. V.; Jiménez, P.; Notario, R.; Temprado, M.; MartínValcarcel, G.; Liebman, J. F. ARKIVOC 2005, ix, 364-374.

(59) Temprado, M.; Roux, M. V.; Jiménez, P; Guzmán-Mejía, R.; Juaristi, E. Thermochim. Acta 2006, 441, 20-26.

(60) Roux, M. V.; Temprado, M.; Jiménez, P.; Notario, R.; Verevkin, S. P.; Liebman, J. F. J. Phys. Chem. A 2006, 110, 12477-12483.

(61) Chaloner, P. A.; Gunatunga, S. R.; Hitchcock, P. B. Acta Crystallogr. 1994, C50, 1941-1942.

(62) Plato, C.; Glasgow, A. R. Anal. Chem. 1969, 41, 331.

(63) Sarge, S. M.; Gmelin, E.; Höhne, G. W.H.; Cammenga, H. K; Hemminger, W.; Eysel, W. Thermochim. Acta 1994, 247, 129.

(64) GEFTA (Gesellschaft für Thermische Analyse, Germany): Gmelin, E.; Sarge, S. M. Pure Appl. Chem. 1995, 67, 1789.

(65) Sabbah, R.; Xu-wu, A.; Chickos, J. S.; Planas, M. L.; Roux, M. V.;

Torres, L. A. Thermochim. Acta 1999, 331, 93.

(66) Roux, M. V.; Temprado, M.; Jiménez, P.; Guzmán-Mejía, R.; Juaristi, E.; Chickos, J. S. Thermochim. Acta 2003, 406, 9-16.

(67) Ribeiro da Silva, M. A. V.; Gonçalves, J. M.; Pilcher, G. J. Chem. Thermodyn. 1997, 29, 253-260.

(68) Coops, J.; Jessup R. S.; van Nes, K. G. In Experimental Thermochemistry; Rossini, F. D., Ed.; Interscience: New York, 1956; Vol. 1, Chapter 3.

(69) Santos, L. M. N. B. F. PhD Thesis; University of Porto,1995.

(70) Waddington, G.; Sunner, S.; Hubbard, W. N. In Experimental Thermochemistry; Rossini, F. D., Ed.; Interscience: New York, 1956; Vol., Chapter 7. 1783

(71) Skinner, H. A.; Snelson, A. Trans. Faraday Soc. 1960, 56, 1776-

(72) Good, W. D.; Scott, D. W.; Waddington, G. J. Phys. Chem. 1956, 60, 1080-1089. 1978.

(73) Vogel, A. I. Quantitative Inorganic Analysis; Longman: London,

(74) The NBS Tables of Chemical Thermodynamic Properties. J. Phys. Chem. Ref. Data 1982, 11, Suppl. 2. 558

(75) Washburn, E. N. J. Res. Natl. Bur. Stand. (U.S.) 1933, 10, 525-

(76) Hubbard, W. N.; Scott D. W.; Waddington G. In Experimental Thermochemistry; Rossini, F. D., Ed.; Interscience: New York, 1956; Vol. 1 , Chapter 5.

(77) Wieser, M. E. Pure Appl. Chem. 2006, 78, 2051-2066.

(78) Ribeiro da Silva, M. A. V.; Monte, M. J. S. Thermochim. Acta 1990, 171, 169-183.

(79) Ribeiro da Silva, M. A. V.; Monte, M. J. S.; Santos, L. M. N. B. J. Chem. Thermodyn. 2006, 38, 778-787.

(80) Hehre, W. J., Radom, L., Schleyer, P. v. R., Pople, J. A. Ab Initio Molecular Orbital Theory; Wiley: New York, 1986.

(81) Frisch, M. J. ; Trucks, G. W.; Schlegel, H. B.; Scuseria, G. E.; Robb, M. A.; Cheeseman, J. R.; Montgomery, J. A., Jr.; Vreven, T.; Kudin, K. N.; Burant, J. C.; Millam, J. M.; Iyengar, S. S.; Tomasi, J.; Barone, V.; Mennucci, B.; Cossi, M.; Scalmani, G.; Rega, N.; Petersson, G. A.; Nakatsuji, H.; Hada, M.; Ehara, M.; Toyota, K.; Fukuda, R.; Hasegawa, J.; Ishida, M.; Nakajima, T.; Honda, Y.; Kitao, O.; Nakai, H.; Klene, M.; Li, X.; Knox, J. E.; Hratchian, H. P.; Cross, J. B.; Bakken, V.; Adamo, C.; Jaramillo, J.; Gomperts, R.; Stratmann, R. E.; Yazyev, O.; Austin, A. J.; Cammi, R.; Pomelli, C.; Ochterski, J. W.; Ayala, P. Y.; Morokuma, K. Voth, G. A.; Salvador, P.; Dannenberg, J. J.; Zakrzewski, V. G.; Dapprich, S.; Daniels, A. D.; Strain, M. C.; Farkas, O.; Malick, D. K.; Rabuck, A. D.; Raghavachari, K.; Foresman, J. B.; Ortiz, J. V.; Cui, Q.; Baboul, A. G.; Clifford, S.; Cioslowski, J.; Stefanov, B. B.; Liu, G.; Liashenko, A.; Piskorz,
P.; Komaromi, I.; Martin, R. L.; Fox, D. J.; Keith, T.; Al-Laham, M. A.; Peng, C. Y.; Nanayakkara, A.; Challacombe, M.; Gill, P. M. W.; Johnson, B.; Chen, W.; Wong, M. W.; Gonzalez, C.; Pople, J. A. Gaussian 03, Revision E.01; Gaussian, Inc.: Wallingford, CT, 2004.

(82) Baboul, A.; Curtiss, L. A.; Redfern, P. C.; Raghavachari, K. J. Chem. Phys. 1999, 110, 7650-7657.

(83) Curtiss, L. A.; Redfern, P. C.; Raghavachari, K.; Rassolov, V.; Pople, J. A. J. Chem. Phys. 1999, 110, 4703-4709.

(84) Stephens, P. J.; Devlin, F. J.; Chabalowski, C. F.; Frisch, M. J. J.

Phys. Chem. 1994, 98, 11623-11627.

(85) Becke, A. D. Phys. Rev. A 1988, 38, 3098-3100.

(86) Lee, C.; Yang, W.; Parr, R. G. Phys. Rev. B 1988, 37, 785-789.

(87) Krishnan, R.; Binkley, J. S.; Seeger, R.; Pople, J. A. J. Chem. Phys. 1980, 72, 650 .

(88) Gomes, J. R. B.; Ribeiro da Silva, M. A. V. Int. J. Quantum Chem. 2005, 101, 860 .

(89) Ribeiro da Silva, M. A. V.; Ferreira, A. I. M. C. L.; Gomes, J. R. B. J. Phys. Chem. B 2005, 109, 13356.

(90) Ribeiro da Silva, M. A. V.; Ferreira, A. I. M. C. L.; Gomes, J. R. B. Bull. Chem. Soc. Jpn. 2006, 79, 1852.

(91) Gomes, J. R. B.; Liebman, J. F.; Ribeiro da Silva, M. A. V. Struct. Chem. 2007, 18, 15.

(92) Ribeiro da Silva, M. A. V.; Ferreira, A. I. M. C. L.; Gomes, J. R. B. J. Phys. Chem. B 2007, 111, 2052.

(93) Gomes, J. R. B.; Ribeiro da Silva, M. D. M. C.; Freitas, V. L. S.; Ribeiro da Silva, M. A. V. J. Phys. Chem. A 2007, 111, 7237.

(94) Ribeiro da Silva, M. A. V.; Cabral, J. I. T. A.; Gomes, J. R. B. J. Phys. Chem. A 2008, 112, 12263.

(95) Reed, A. E.; Weinhold, F. J. Chem. Phys. 1983, 78, 4066-4073.

(96) Reed, A. E.; Curtiss, L. A.; Weinhold, F. Chem. Rev. 1988, 88, 899-926.

(97) Weinhold, F. Natural Bond Orbital (NBO) Analysis. In Encyclopedia of Computational Chemistry; Schleyer, P. v. R., Ed.; Wiley: New York, 1998; Vol. 3, p 1792.

(98) Glendening, E. D.; Reed, A. E.; Carpenter, J. E.; Weinhold, F. NBO, version 3.1, Madison, WI, 1988.

(99) Westrum, E. F. In Combustion Calorimety; Sunner, S., Månsson, M., Eds.; Pergamon: Oxford, 1979; Vol. 1, Chapter 7.

(100) Rossini, F. D. In Experimental Thermochemistry; Rossini, F. D., Ed.; Interscience: New York, 1956; Vol. 1, Chapter 14.

(101) Olofsson, G. In Combustion Calorimety; Sunner, S., Månsson,

M., Eds.; Pergamon: Oxford, 1979; Vol. 1, Chapter 6.

(102) CODATA Key Values for Thermodynamics; Cox, J. D., Wagman,

D. D., Medvedev, V. A., Eds.; Hemisphere: New York, 1989.

(103) Burkinshaw, P. M.; Mortimer, C. T. J. Chem. Soc., Dalton Trans. 1984, 75-77.

(104) Ribeiro da Silva, M. A. V.; Amaral, L. M. P. F.; Santos, A. F. L. O. M.; Gomes, J. R. B. J. Chem. Thermodyn. 2006, 38, 367-375.

(105) Ribeiro da Silva, M. A. V.; Amaral, L. M. P. F.; Santos, A. F. L. O. M.; Gomes, J. R. B. J. Chem. Thermodyn. 2006, 38, 748-755.

(106) Hubbard, W. N.; Scott, D. W.; Frow, F. R.; Waddington, G. J. Am. Chem. Soc. 1955, 77, 5855-5858.

(107) Experimental enthalpy of formation for benzene, $82.6, \mathrm{~kJ} \mathrm{~mol}^{-1}$, has been taken from: Pedley, J. B. Thermochemical Data and Structures of Organic Compounds; TRC Data Series; Thermodynamics Research Center: College Station, TX, 1994,; Vol. 1. Value for biphenyl, $182.0 \mathrm{~kJ} \mathrm{~mol}^{-1}$, has been taken from: Chirico, R. D.; Knipmeyer, S. E.; Nguyen, A.; Steele, W. V. J. Chem. Thermodyn. 1989, 21, 1307-1331.

(108) Anantharaman, B.; Melius, C. F. J. Phys. Chem. A 2005, 109, 1734-1747.

(109) Chase, M. W. NIST-JANAF Thermochemical Tables, Fourth Edition. J. Phys. Chem. Ref. Data, Monogr. 1998, No. 9, 1-1951.

(110) Barckholtz, C.; Barckholtz, T. A.; Hadad, C. M. J. Am. Chem. Soc. 1999, 121, 491-500.

(111) Almenningen, A.; Bastiansen, O.; Fernholt, L.; Skancke, A. Acta Chem. Scand. 1970, 24, 1389-1397.

JP905531C 